\title{
FESTIVAL HERITAGE OMED-OMEDAN SEBAGAI DAYA TARIK WISATA DI SESETAN, DENPASAR
}

\author{
I Wayan Didik Roy Mahardika \\ mahardika_didik@yahoo.com
}

\begin{abstract}
Despiteits naturalbeauties, Baliis alsowell-known for its traditional cultures which can attract many tourists to come. Along with the development of tourism, traditional cultures are performed as tourist attractions. This article analyses the development of omedomedan thug of war in Banjar Kaja, Sesetan Village, Denpasar, as atourist attraction. This tradition has been praticed for many decades yet since 2009, the community adopted it as "Sesetan Heritage Omed-omedan Festival" (SHOOF) with two aims, that is to support the Denpasar as "city of cultural" and to perform the tradition in a more professional festival thus not only to maintain the pride of young generation of the local community to preserve their tradition, but also as a unique tourist attraction in an urban setting. Survei was coducted to get perception of both local people and visitors who watch the festival. The article concludes that Sesetan Heritage Omed-omedan Festival has a great potential to develop as a cultural icon for Denpasar tourism. However, to make it a more an attractive event for visitors management improvement is required.
\end{abstract}

Keywords : omed-omedan festival, cultural heritage, tourist attraction, local community.

\section{Pendahuluan}

Seni budaya yang unik memiliki potensi besar sebagai daya tarik wisata karena wisatawan senantiasa tertarik untuk melihat atau menyaksian apa yang tidak mereka miliki. Makin banyak sebuah daerah memiliki tradisi yang unik, makinkuat daya tarik daerah tersebut sebagai destinasi wisata. Bali bisa disebutkan sebagai contoh. Pulau yang kecil ini memiliki banyak tradisi unik. Dari potensi seni budaya yang unik inilah, Bali berkembang menjadi destinasi wisata budaya. Keindahan alamnya merupakan pendukung dari keunikan budaya yang dimiliki Bali.

Tradisi yang unik di Bali tersebar di berbagai daerah. Di Tenganan 
Pageringsingan, misalnya terdapat tradisi Perang Pandan yang memikat banyak wisatawan setiap tradisi ini digelar setahun sekali. Selain itu, keunikan budaya Tenganan juga terlihat dari pola menetap penduduk dalam sebuah kantong (enclave) desa dengan sistem budaya Bali Kuna. Desa Trunyan di Kabupaten Bangli memiliki budaya yang unik, yakni penguburan mayat tanpa ditanam sebagaimana lazimnya di tepi Danau Batur yang indah. Tradisi unik di desa Bali Kuna ini juga merupakan daya tarik wisata. Kegiatan ngaben utama di Puri Ubud juga merupakan tradisi yang memikat, buktinya setiap ada kremasi besar di Ubud, wisatawan datang berduyun, membuat Ubud mampu mempertahankan citranya sebagai desa wisata budaya.

Tradisi budaya yang unik di Bali tidak saja terdapat di desa-desa Bali Kuna, tetapi juga di desa-desa modrn di perkotaan. Banjar Kaja, Desa Sesetan, Denpasar, memiliki tradisi yang unik yang dilestarikan dan potensial dijadikan daya tarik wisata, yaitu omed-omedan. "Omed-omedan" berdasarkan kamus Bali-Indonesia memiliki kata dasar "omed” yang berarti "tarik", sehingga "omed-omedan" berarti "tarik menarik satu sama lain". Tradisi ini diadakan pada hari ngembak geni yaitu sehari setelah perayaan Hari Raya Nyepi, tahun Baru Caka. Nyepi adalah perayaan yang unik karena pada hari ini di Bali diterapkan empat larangan (catur beratha) yaitu tidak boleh menyalakan api (amati gni), tidak boleh bepergian (amati lelungan), tidak boleh bekerja (amati karya). Pada hari ini, Bali seperti menjadi kota mati, tidak ada orang bepergian di jalan raya, malam hari gelap gulita karena tidak boleh menyalakan lampu.

Sehari menjelang Nyepi, malam harinya, berlangsung ritual ngerupuk yang ditandai dengan pengarakan ogoh-ogoh diiringi gamelan riuhrendah di hampir seluruh pelosok Bali. Di Denpasar, kota yang bertekad menjadi kota berwawasan budaya, dilaksanakan pawai ogoh-ogoh yang dikelola dengan sistem lomba. Kreasi ogoh-ogoh biasanya muncul sangat kreatif sehingga juga menjadi daya tarik wisatawan. Sehari setelah Nyepi, berlangsung tradisi Omed-omedan di Banjar Kaja Sesetan. Tarik-tarikan ini dilaksanakan di jalan raya, ada dua grup muda-mudi yang melakukan tarik-tarikan dan dalam keadaan ramai demikian terjadi dorong-dorongan sampai muda-mudi "berciuman" (Foto 1).

Pelaksanaan tradisi omed-omedan secara kualitatif menunjukkan perkembangan yang sangat menggembirakan. Artinya, pelaksanaan tradisi ini telah menunjukkan suatu keberhasilan dari upaya pelestarian budaya. Indikasi keberhasilan pelestarian budaya ini adalah keberlanjutan tradisi ini dari waktu ke waktu dengan keterlibatan penuh dari seluruh komponen di Banjar Kaja. Karena keberhasilan inilah maka berkembang wacana untuk mengembangkan tradisi ini menjadi suatu obyek wisata yang bertujuan selain meningkatkan kesejahteraan masyarakat juga untuk menunjang kelestarian tradisi itu sendiri. 


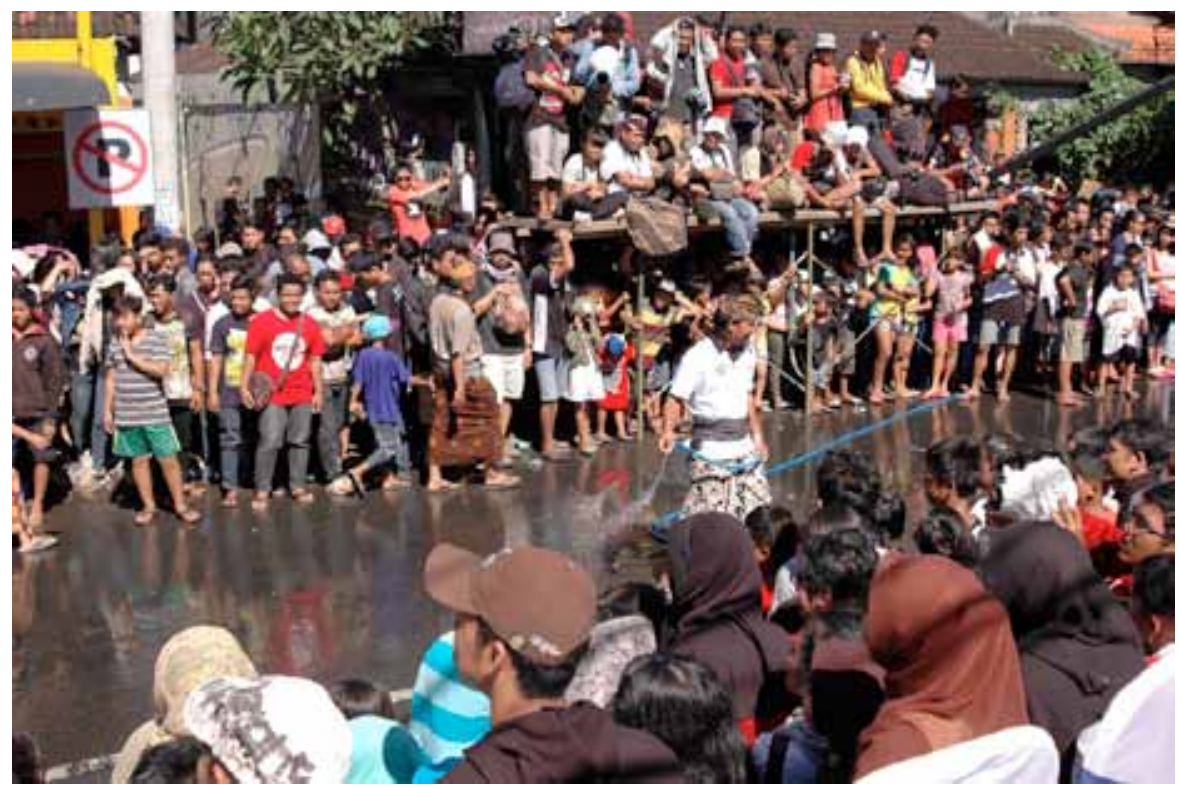

Foto 1. Arena pelaksanaan Sesetan Heritage Omed-omedan Festival (Foto: Komang Teddy)

Tulisan ini mengkaji pelestarian tradisi unik omed-omedan dan perkembangannya sebagai daya tarik wisata. Penelitian ini dilakukan di Banjar Kaja, Desa Sesetan, yang terletak di Denpasar, Provinsi Bali, pada bulan Januari sampai dengan Juni 2013. Pengembangan sebuah tradisi yang menjadi bagian hidup dan jati diri suatu komunitas perlu dilakukan dengan terus-menerus. Tujuannya agar warisan tradisi budaya tidak punah sehingga tetap dapat dipertahankan sebagai identitas komunitas atau warga masyarakat. Secara spesifik, artikel ini melakukan pengkajian pada dua faktor yaitu secara internal dan eksternal, dengan tujuan (1) untuk mengetahui apakah tradisi omed-omedan dapat menjadi daya tarik wisata internasional, (2) mengetahui apakah omed-omedan merupakan budaya local penting yang menjadi wisata, (3) mengetahui faktor-faktor yang mendorong Krama Banjar Kaja untuk melaksanakan tradisi omed-omedan, (4) mengetahui faktor-faktor yang dipertimbangkan oleh para wisatawan untuk mengunjungi tradisi omed-omedan di Banjar Kaja Sesetan, (5) mengetahui hambatan dari tradisi omed-omedan untuk menjadi daya tarik wisata internasional.

Penelitian ini menggunakan metodologi dengan beberapa jenis metode, seperti melakukan survei menggunakan kuesioner untuk masyarakat Banjar Kaja dan pengunjung, observasi, wawancara dan juga kajian literatur. Teknik analisis data yang digunakan untuk menjawab permasalahan adalah metode kualitatif dan kuantitatif. 


\section{Modernisasi dalam Tradisi "Omed-omedan"}

Ada banyak pengertian teoritik mengenai modernisasi. Budiman dan Schuurman (dalam Purwana 2011) menyampaikan beberapa teori modernisasi. Budiman menyatakan bahwa teori modernisasi merupakan hasil pemikiran sarjana ilmu sosial Amerika yang tertarik untuk menjawab pertanyaan mengapa negara-negara di Dunia Ketiga pembangunannya tidak sesukses negara-negara di Eropa dan Amerika. Teori modernisasi telah menjadi kerangka pemikiran tunggal untuk menjelaskan jalan menuju tercapainya peningkatan kesejahteraan hidup bangsa di negara-negara sedang berkembang termasuk Indonesia.

Modernisasi merupakan konsep yang menggambarkan perubahan sosial di kawasan yang sedang berkembang. Proses modernisasi ditafsirkan sebagai proses menuju tipe sosial, ekonomi dan politik yang telah berkembang di Eropa Barat dan Amerika Utara. Soekanto (dalam Anam 2011) menyebutkan bahwa modernisasi tidak terjadi begitu saja, melainkan terjadi karena adanya faktor pendukung yang menunjang terjadinya suatu perubahan. Beberapa syarat suatu modernisasi dapat terjadi adalah sebagai berikut.

1. Cara berpikir yang ilmiah yang melembaga dalam kelas penguasa maupun masyarakat. Hal ini menghendaki suatu sistem pendidikan dan pengajaran yang terencana dan baik.

2. Sistem administrasi negara yang baik, yang benar-benar mewujudkan birokrasi

3. Adanya pengumpulan data yang baik dan teratur dan terpusat pada suatu lembaga atau badan tertentu. Hal ini memerlukan penelitian yang berlanjut agar mereka tidak tertinggal.

4. Penciptaan iklim yang farodable dari masyarakat terhadap modernisasi dengan cara penggunaan alat-alat komunikasi massa. Hal ini harus dilakukan tahap demi tahap karena banyak sangkut pautnya dengan sistem kepercayaan masyarakaat (belief system).

5. Tingkat organisasi yang tinggi, di satu pihak berarti disiplin, sedangkan dilain pihak berarti pengurangan kemerdekaan.

6. Sentralisasi wewenang dalam pelaksanaan perencanaan sosial (social planning) apabila itu tidak dilakukan, perencanaan akan terpengaruh oleh kekuatan-kekuatan dari kepentingan-kepentingan yang ingin mengubah perencanaan tersebut demi kepentingan golongan kecil dalam masyarakat.

Kartawinata (2011) menyatakan bahwa modernisasi dalam kehidupan manusia secara umum dapat diamati dari perubahan tradisi lokal dalam suatu kebudayaan yang berkembang dari waktu ke waktu. Kebudayaan sebagai wahana dan wacana bagi masyarakat untuk terus menerus menyesuaikan diri atau merespons perubahan baik yang diakibatkan dari dalam maupun perubahan dari luar kebudayaannya tanpa harus menghilangkan 
identitas kebudayaannya. Respons penyesuaian diri masyarakat seperti itulah yang kemudian dikenal sebagai proses untuk menjadi pintar dan berpengetahuan warga masyarakat guna mempertahankan dan melangsungkan kehidupannya. Peneguhan terus menerus hal serupa itu, dalam praktek kebudayaan dikenal sebagai tradisi.

Lerner (dalam Muthe (2008) menjelaskan hasil penelitiannya di Timur Tengah. Dalam penelitian tersebut,dia menggambarkan modernisasi sebagai faktor yang mendorong perubahan sosial di Timur Tengah. Secara umum, hasil penelitiannya menemukan nilai-nilai tradisional yang tercermin dalam tingkah laku manusia pada masyarakat Timur Tengah mengalami peralihan ke karakter kehidupan modern. Tiga variabel modernisasi yang digunakan Lerner yaitu; 1) lebih modern, dimaksudkan lebih banyak orang yang mengubah cara hidup tradisional, 2) lebih dinamis, dimaksudkan modernisasi berjalan dengan suatu derap cepat; 3) lebih stabil, dimaksudkan pembagian kelas tidak begitu jelas. Modernisasi lebih bergerak cepat karena tidak dihambat oleh terputusnya kebijakan dan dinamika sosial politik. Ketiga variabel itu diturunkan pada beberapa kondisi yang dapat ditelaah yaitu; mobilitas, empati, pendapatan dan partisipasi.

Modernisasi juga tak dapat dihindari dalam pelaksanaan tradisi omedomedan, namun demikian masyarakat Banjar Kaja khususnya yang beragama Hindu hingga saat ini masih kuat kepercayaannya pada manfaat tradisi ini dan ritualnya juga tidak mengalami perubahan. Karena itu, dapat disimpulkan bahwa kearifan lokal dalam tradisi ini belumlah hilang. Simpulan kedua adalah jati diri Masyarakat Banjar Kaja sebagai penyungsung tradisi omed-omedan masihlah terjaga.

Pengkajian secara lebih mendalam dengan menggunakan variabel ukur yang dikembangkan oleh Lerner menunjukkan bahwa modernisasi pada tradisi omed-omedan memang terjadi. Namun, modernisasi tersebut lebih kepada perubahan manajemen pengelolaan tradisi ini yang semakin profesional. Tampilan lainnya adalah penambahan sarana perbelanjaan di sepanjang areal penyelenggaraan. Modernisasi rupanya tidak menyentuh pada kepercayaan akan manfaat dan dampak buruk dari tradisi ini. Pelaksanaan prosesi ritual juga tidak tersentuh modernisasi. Ini dilihat dari tidak ditemukannya perubahan yang substansial pada setiap tahapan ritual. Ide kreatif dari warga setempat dan didukung oleh pemerintah Kota Denpasar, tradisi omed-omedan diangkat sebagai heritage, tradisi yang dilestarikan agar tetap terjadi pada masa dewasa ini (Foto 2 dan 3).

\section{Persepsi Wisatawan pada Omed-omedan}

Bali sejak awal telah mencanangkan pengembangan pariwisata budaya sesuai dengan potensi budaya yang dimiliki. Program tersebut sudah diatur dalam peraturan daerah (Perda). Perda Pariwisata Budaya sudah mengalami 


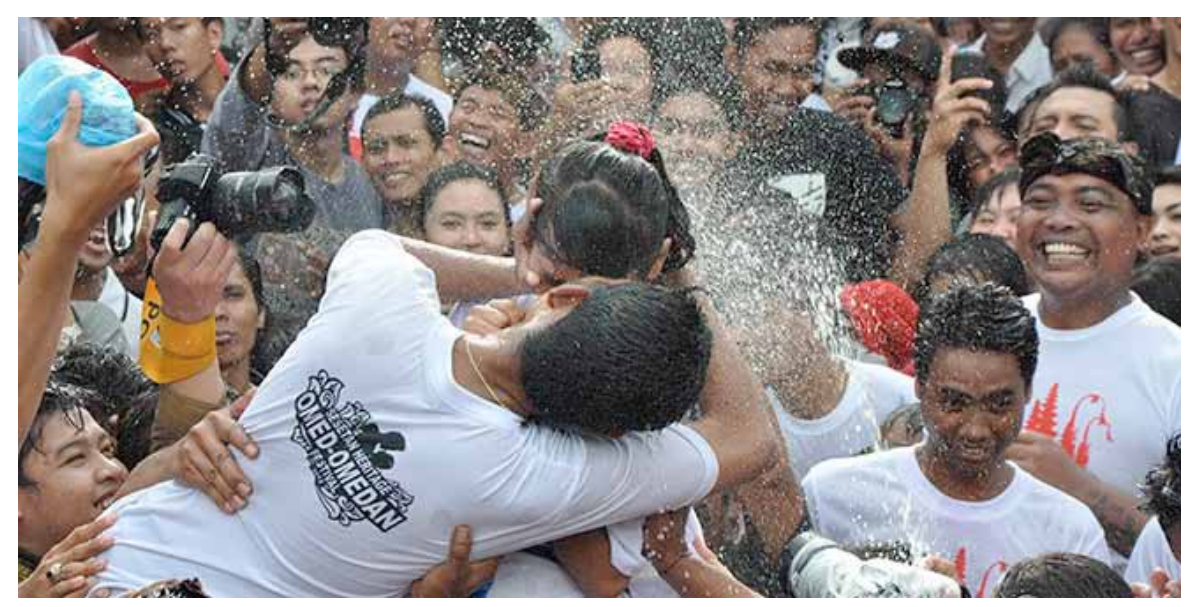

Foto 2. Sesetan Heritage Omed-omedan Festival (Sumber: Weeklylinenet/ by Sandrowangak)

revisi tiga kali untuk menguatkan pengembangan kepariwisataan berdasarkan budaya, dan sebalinya budaya akan dapat berkembang dari keuntungan ekonomi pariwisata. Hadirnya Peraturan Daerah Provinsi Bali Nomor 2 Tahun 2012 Tentang Kepariwisataan Budaya Bali telah adalah indikasi penguatan pembangunan destinasi wisata yang makin beragam.

Bila mengacu pada Peraturan Daerah Provinsi Bali Nomor 2 Tahun 2012 tentang Kepariwisataan Budaya Bali pada Pasal 12, omed-omedan dapat digolongkan sebagai tradisi yang berpotensi sebagai daya tarik wisata. Karena potensinya inilah maka upaya pengembangan perlu dilakukan. Langkah awal dari pengembangan tradisi ini tentunya dengan mengidentifikasikan persepsi dari wisatawan. Identifikasi persepsi wisatawan ini dilakukan dengan menyebarkan alat pengumpulan data yang berupa kuesioner. Kuesioner ini memuat berbagai variabel yang dinilai dapat mempengaruhi keputusan dari wisatawan untuk menyaksikan tradisi omed-omedan ini. Variabel-variabel yang dimaksud adalah sebagai berikut.

1) Kemudahan jangkauan lokasi.

2) Waktu penyelenggaraan.

3) Keunikan tradisi.

4) Penerapan nilai-nilai luhur dalam tradisi.

5) Kebanggaan pada tradisi.

6) Tradisi memberikan semangat

7) Rasa ingin tahu.

8) Penciptaan pemahaman bagi masyarakat adat setempat.

9) Agenda tetap pariwisata dunia.

10) Promosi pariwisata.

11) Paket atraksi.

12)Kenyamanan dalam menikmati dan memahami tradisi 


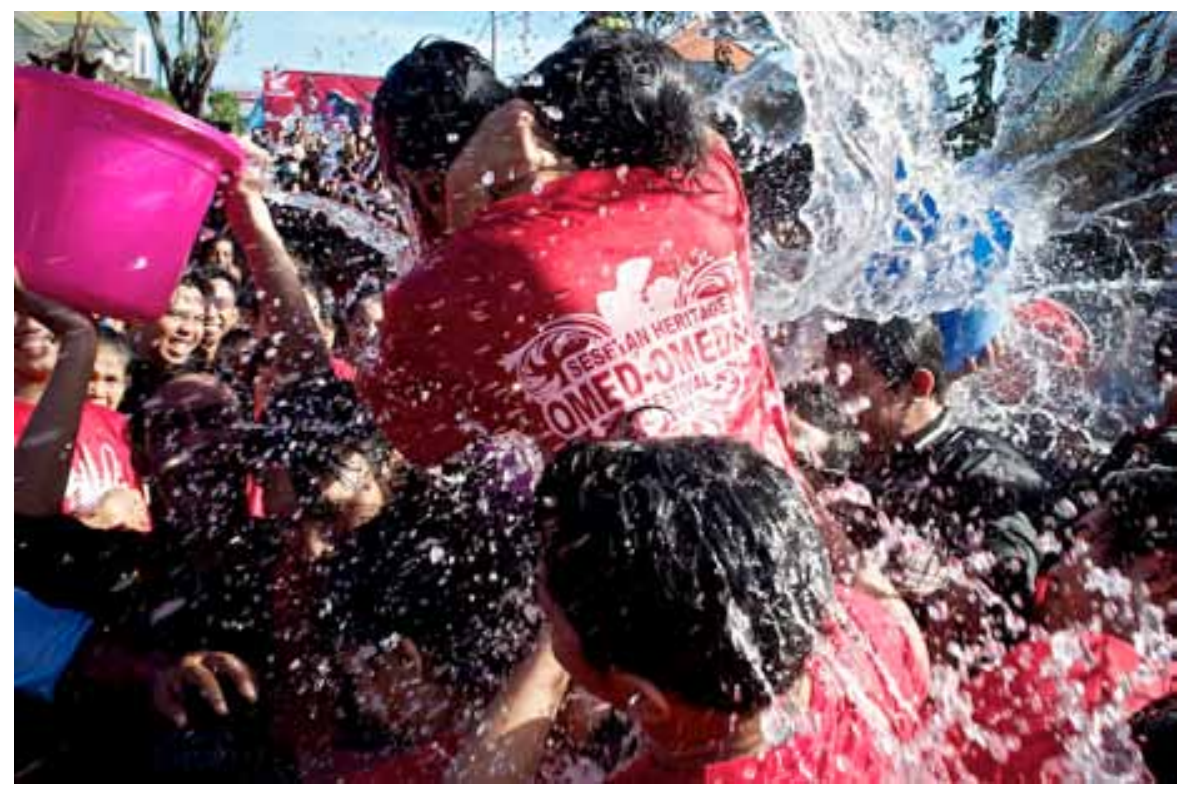

Foto 3. Kegiatan Festival Omend-omedan diikuti anak-anak muda (Sumber: Balebengong/Foto Anggara Mahendra)

Kuesioner ini disebarkan kepada pengunjung baik domestik maupun manca negara dan Krama Banjar Kaja Desa Sesetan. Teknik sampling menggunakan teknik random dengan memberi kesempatan sama pada setiap anggota sampel (probability random sampling). Jumlah keseluruhan untuk wisatawan adalah 139 orang responden, dengan rincian wisatawan domestik 133 responden dan manca negara 6 responden. Jumlah keseluruhan untuk Krama Banjar Kaja adalah sebanyak 94 responden.

Berdasarkan hasil survei yang dilakukan terhadap 12 variabel tersebut didapatkan hasil sebagai berikut. Ada $65.4 \%$ wisatawan domestik dan $66.7 \%$ wisatawan manca negara menyatakan setuju dan 54.3\% Krama Banjar Kaja menyatakan sangat setuju bahwa lokasi penyelenggaraan Sesetan Heritage Omed-omedan Festival (SHOOF) sangat mudah untuk dijangkau. Pada variabel waktu penyelenggaraan didapatkan hasil $64.7 \%$ wisatawan domestik, 50\% wisatawan manca negara dan 56.4\% Krama Banjar Kaja menyatakan setuju bahwa waktu penyelenggaraan diadakannya SHOOF telah sesuai. Selanjutnya 60.9\% wisatawan domestik sangat setuju, 83.3\% wisatawan manca negara dan 62.8\% Krama Banjar Kaja menyatakan setuju SHOOF merupakan sebuah tradisi yang memiliki keunikan.

Variabel selanjutnya adalah penerapan nilai-nilai luhur dalam tradisi, sebesar $54.1 \%$ wisatawan domestik, 50\% wisatawan manca negara dan 57.4\% krama Banjar Kaja menyatakan setuju bahwa di dalam tradisi omedomedan ini terdapat penerapan nilai-nilai luhur. Selanjutnya sebesar 60.9\% wisatawan domestik menyatakan setuju, 64.9\% krama Banjar Kaja 
menyatakan setuju bahwa tradisi ini menimbulkan kebanggaan. Namun, untuk wisatawan manca negara sebesar $33.3 \%$ yang menyatakan setuju dan $33.3 \%$ menyatakan kurang setuju akan hal tersebut. Selanjutnya $59.4 \%$ wisatawan domestik dan $66.7 \%$ wisatawan manca negara menyatakan setuju, serta $48.9 \%$ krama Banjar Kaja mengatakan sangat setuju hadir dalam tradisi ini menimbulkan semangat.

Pada variabel selanjutnya terdapat $52.6 \%$ wisatawan domestik dan 55.3 krama Banjar Kaja menyatakan setuju, sedangkan responden wisatawan manca negara 50\% menyatakan setuju dan 50\% sangat setuju hadir dalam SHOOF ini adalah sebagai bentuk untuk memenuhi rasa ingin tahu pada tradisi ini. Pada variabel penciptaan pemahaman bagi masyarakat adat setempat terdapat $60.9 \%$ wisatawan domestik, $83.3 \%$ wisatawan mancanegara dan 57.4\% krama banjar kaja menyatakan setuju bahwa tradisi omed-omedan memberikan pemahaman tentang budaya masyarakat di Banjar Kaja. Selanjutnya, sebesar $51.1 \%$ wisatawan domestik menyatakan sangat setuju, 50\% wisatawan manca Negara kurang setuju dan 61.7\% krama banjar kaja menyatakan setuju jika SHOOF dimasukkan dalam agenda tetap pariwisata dunia.

Hasil survey terhadap variabel peningkatan promosi pariwisata, sebesar $54.9 \%$ wisatawan domestik dan 50\% wisatawan mancanegara menyatakan sangat setuju, serta 54.3\% krama Banjar Kaja menyatakan setuju mengenai diperlukannya peningkatan promosi. Selanjutnya sebesar $45.1 \%$ wisatawan domestik menyatakan setuju setuju dan $66 \%$ krama banjar kaja sangat setuju bahwa pengunjung yang datang pada SHOOF dikarenakan oleh paket atraksi lainnya, seperti wisata kuliner, tempat belanja, serta hiburan lainnya. Terjaring $66.7 \%$ wisatawan mancanegara kurang setuju akan hal tersebut. Variabel terakhir menunjukan 51.1\% wisatawan domestik dan krama Banjar Kaja menyatakan setuju telah mendapatkan kenyamanan dalam menikmati dan memahami tradisi omed-omedan. Bagi wisatawan mancanegara terdapat presentase sebesar $33.3 \%$ yang menyatakan setuju dan kurang setuju terhadap hal tersebut.

\section{Hambatan omed-omedan sebagai Atraksi Pariwisata Internasional}

Pengembangan sebuah peristiwa budaya sebagai daya tarik wisata memerlukan beberapa persyaratan, demikian pula halnya dengan omed-omedan. Menurut Soebagyo (2012), pengembangan pariwisata dapat dilakukan dengan memperhatikan syarat-syarat berikut :

Pertama, adanya peraturan yang mengikat dan mengatur setiap komponen yang terlibat dalam penyelenggaraan tradisi. Hal yang perlu ditambahkan terkait dengan aturan yang mengatur etika pengunjung atau penonton agar tidak mengganggu jalannya tradisi, dan penegasan sanksi bagi yang melanggar aturan-aturan tersebut. 
Kedua, pengelolaan daya tarik wisata ini dilakukan oleh masyarakat Banjar Kaja, Kelurahan Sesetan mulai dari persiapan hingga puncak pelaksanaannya.

Ketiga, sejauh ini belum diadakan penganekaragaman jenis promosi untuk memperkenalkan tradisi ini di daerah-daerah di luar Kelurahan Sesetan. Untuk itu perlu diadakan promosi dalam berbagai cara, sejauh tidak melanggar aturan yang ada, agar lebih menarik minat wisatawan untuk berkunjung pada saat tradisi ini dilaksanakan.

Keempat, daya tarik wisata di Banjar Kaja, Kelurahan Sesetan adalah tradisi omed-omedan itu sendiri.

Kelima, kerja sama antar berbagai pihak yang dapat menunjang promosi dan pelaksanaan tradisi ini harus lebih ditingkatkan. Baik itu kerja sama antar pengurus Banjar Kaja dengan pemerintah Kelurahan Sesetan, pemerintah Kecamatan Denpasar Selatan, menjalin kerja sama dengan pemerintah Kota Denpasar maupun dengan dinas-dinas terkait di tingkat provinsi Bali. Selain itu, kerja sama dengan berbagai travel agent, maupun biro-biro pariwisata juga perlu ditingkatkan untuk menunjang promosi dan menarik wisatawan untuk menyaksikan pelaksanaan tradisi omed-omedan di Banjar Kaja, Kelurahan Sesetan.

Keenam, peningkatan kerja sama pada poin di atas akan berimbas pada arus wisatawan yang menyaksikan tradisi ini. Jadi, wisatawan tidak lagi didominasi oleh wisatawan domestik, namun juga dari manca negara.

Ketujuh, perlu diadakannya penguatan jati diri warga Banjar Kaja, Kelurahan Sesetan dalam rangka mempersiapkan diri tradisi omed-omedan menjadi agenda tetap pariwisata dunia. Hal ini perlu dilakukan mengingat peran tradisi ini di wilayah Banjar Kaja yang nantinya akan menjadi tempat berkumpulnya para wisatawan, sehingga hal ini sebaiknya dapat dimanfaatkan oleh masyarakat asli Banjar Kaja, Kelurahan Sesetan dengan turut berpartisipasi aktif dan memanfaatkan peluang-peluang yang ada. Misalnya, berpartisipasi dalam penambahan paket atraksi seperti wisata kuliner, dan wisata belanja hasil kerajinan masyarakat. Namun, partisipasi masyarakat ini agar tidak terlepas dari jati diri warga Banjar Kaja, yakni upaya pelestarian tradisi omed-omedan agar tetap eksis.

Kedelapan, peningkatan tradisi omed-omedan sebagai agenda tetap wisata dunia perlu didukung dengan adanya penyediaan sarana dan prasarana sesuai dengan kwalitas dan kwantitas yang memadai. Kendala para wisatawan selama ini terkait dengan sarana dan prasarana tradisi sehingga menimbulkan ketidaknyamanan dalam menikmati dan memahami tradisi ini. Maka dari itu, perlu diadakan perluasan jalan, perluasan tempat atraksi, penambahan atap, dan lain sebagainya. 


\section{Omed-omedan sebagai daya tarik wisata}

Tradisi omed-omedan sebagai sebuah hasil budaya dari suatu masyarakat tentunya memiliki keunikan yang menjadi ciri khas masyarakat pemiliknya. Sebuah tradisi yang berkembang dari masa lalu pada era masa kini bukan hanya berfungsi sebagai sarana pencapaian dari makna dasar tradisi tersebut. Perkembangan pola pikir manusia dengan berbagai macam pembaharuan yang terjadi telah mengubah pola pikir manusia pada sebuah tradisi yang bersifat tradisional. Realisasi sebuah tradisi pun berkembang menjadi media hiburan di era modern ini.

Hiburan yang berasal dari wujud sebuah tradisi pada banyak kasus sangat sulit dinikmati oleh mereka yang berasal dari luar komunitas masyarakat yang memiliki budaya tersebut. Suatu contoh adalah tradisi omedomedan yang pada puncaknya sering terjadi gesekan antara muda-mudi yang berakibat terjadinya aktivitas berciuman. Aktivitas berciuman antar individu berbeda jenis kelamin di depan umum dalam budaya di Indonesia dan banyak lagi di dunia ini dianggap sebagai hal yang tabu atau melanggar etika kesopanan. Karena itulah, saat sebuah wacana pengembangan tradisi tradisional menjadi obyek wisata mengemuka maka langkah awal yang perlu dilakukan adalah mengembangkan pemahaman tentang filosofi sebuah tradisi. Harapannya adalah dengan hadirnya pemahaman tersebut maka masyarakat dapat menikmati aspek hiburan yang terdapat dalam tradisi tersebut.

Pengembangan filosofi tentang tradisi omed-omedan pada saat ini masih berkembang di seputaran masyarakat Banjar Kaja. Dampaknya adalah tradisi ini secara utuh masih menjadi milik dari masyarakat setempat. Rasa memiliki sebuah tradisi dalam konteks pariwisata internasional sangatlah penting. Karena dengan adanya rasa ikut memiliki ini akan mendorong seluruh pemangku kepentingan (stakeholder) dalam dunia pariwisata akan terlibat proaktif pada upaya pengembangan tradisi ini sebagai daya tarik wisata internasional.

Pengembangan pemahaman filosofis dalam tradisi omed-omedan atau tradisi lain yang bersifat tradisional menjadi sangat penting dalam pengembangan segmen pasar pariwisata. Seorang wisatawan yang memahami filosofi dari sebuah tradisi dalam masyarakat akan menjadi konsumen yang loyal untuk hadir pada setiap penyelenggaraan tradisi dalam suatu kurun waktu yang panjang. Ini dapat dibuktikan dari hasil wawancara pada wisatawan pengunjung tradisi omed-omedan yang berasal dari luar Banjar Kaja. Para wisatawan umumnya hanya penasaran saja pada tradisi dimana didalamnya terdapat aktivitas berciuman di depan umum tersebut dilakukan. Saat mereka telah mengetahuinya maka kepuasan itu hanya berhenti sampai disana. Bila pada tahun berikutnya mereka hadir di pagelaran tradisi omed-omedan ini maka mereka akan menikmati aktivitas lainnya seperti berbelanja suve- 
nir atau wisata kuliner.

Mengacu pada hasil wawancara pada wisatawan yang hadir dalam Tradisi omed-omedan maka dapat disimpulkan bahwa segmen pariwisata dari tradisi ini masih terbatas pada masyarakat lokal yang menjadi pemilik tradisi. Pariwisata yang dimaksud adalah pariwisata yang berkelanjutan (sustainable tourism). Pariwisata yang berkelanjutan tentunya memerlukan loyalitas pengunjung untuk hadir kembali pada periode event berikutnya dengan membawa serta individu lainnya. Masih terbatasnya segmen pasar pariwisata dari tradisi ini sangat disayangkan, mengingat potensi dari tradisi ini yang sangat potensial untuk menjadi daya tarik wisata internasional.

\section{Upaya Pemerintah serta Dukungan Masyarakat}

Visi dari Dinas Pariwisata Kota Denpasar adalah "terwujudnya Kota Denpasar sebagai kota pariwisata budaya yang berkelanjutan dilandasi Tri Hita Karana”. Selanjutnya untuk mewujudkan visi tersebut guna memberikan arah dan tujuan yang ingin dicapai, memberikan fokus terhadap program yang akan dilaksanakan dan untuk menumbuhkan partisipasi semua pihak, maka ditetapkan misi sebagai berikut: :

a. Mengembangkan objek dan daya tarik wisata yang berdasarkan kearifan lokal

b. Membangun sarana dan prasarana dalam keselarasan dan keharmonisan lingkungan

c. Mewujudkan kualitas pelayanan yang baik kepada masyarakat

d. Mengoptimalkan sarana informasi dan menyelenggarakan promosi yang lebih berkualitas.

Dari visi dan misi tersebut pemerintah kota Denpasar sangat mendukung dengan adanya berbagai kegiatan budaya yang ada di Kota Denpasar. Perkembangan pariwisata di kota Denpasar mengalami peningkatan setiap tahunnya baik wisatawan domestik maupun mancanegara. Hal ini merupakan sebuah potensi yang dapat digunakan untuk meningkatkan pendapatan baik secara makro maupun mikro melalui sektor pariwisata yang dapat dicapai melalui pariwisata budaya sesuai dengan visi dan misi dari kota Denpasar.

Omed-omedan merupakan salah satu budaya warisan leluhur di kota Denpasar yang hingga kini tetap diselenggarakan oleh warga Banjar Kaja dan mengalami perkembangan menjadi bentuk festival yang diberi nama "Sesetan Heritage Omed-omedan Festival" (SHOOF) sejak tahun 2009 dengan berbagai atraksi pendukung serta mendapat perhatian dan dukungan dari pemerintah kota Denpasar (Foto 4).

Pariwisata di Denpasar sama seperti pariwisata yang dikembangkan di seluruh kawasan Provinsi Bali. Pariwisata di Bali dikembangkan oleh dua pihak yaitu swasta mulai dari skala mikro hingga makro, pihak kedua adalah 
desa adat. Pemerintah di semua tingkatan (provinsi, kota dan kabupaten) berperan membangun dan memelihara infrastruktur penunjang aktivitas wisata seperti pembangunan jalan, instalasi air bersih dan kebersihan.

Pemerintah Kota Denpasarjuga berperan dalam upaya perbaikan sarana dan prasarana penunjang Sesetan Heritage Omed-omedan Festival (SHOOF) namun tidak berperan banyak, hal ini karena atraksi wisata omed-omedan ini dimiliki dan diselenggarakan oleh Banjar Kaja Desa Sesetan. Pengelolaan perbaikan tersebut diserahkan kepada Banjar Kaja. Pemerintah kota Denpasar hanya berperan sebagai fasilitator upaya pengembangan tradisi ini sebagai daerah tujuan wisata. Wujud fasilitasi ini adalah pembinaan adat oleh Dinas

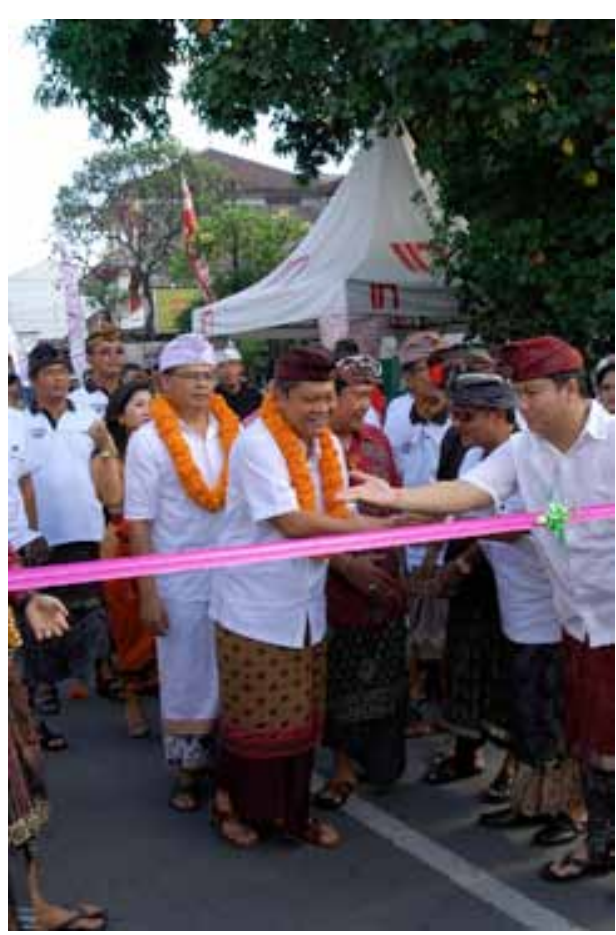

Foto 4. Walikota Denpasar Ida Bagus Rai Dharmawijaya Mantra dalam suatu acara Omed-omedan Festival

(Sumber: Komang Teddy).

Kebudayaan Kota Denpasar, pembinaan pengelolaan daerah tujuan wisata oleh Dinas Pariwisata Kota Denpasar dan bantuan dana pada setiap penyelenggaraan SHOOF.

Berdasarkan informasi yang berhasil dihimpun di dinas pariwisata daerah kota Denpasar menunjukkan bahwa Sesetan Heritage Omed-omedan Festival sejak tahun 2010 telah masuk dalam kalender wisata tahunan Kota Denpasar yang diselenggarakan sehari setelah hari raya Nyepi. Dukungan lain pun dilakukan pemerintah kota dengan melakukan promosi melalui media internet. Saat dinas pariwisata daerah kota Denpasar melakukan kunjungan ke luar negeri dalam rangka promosi wisata maka informasi tentang tradisi ini juga disajikan dalam bentuk brosur hingga film dokumenter. Bentuk nyata tradisi ini tentunya tidak dapat dilakukan di luar Banjar Kaja. Hal ini sebagai bentuk penghormatan atas kesakralan dari tradisi ini.

Kebudayaan dan tradisi tidak hanya memiliki dampak ekonomi, tapi juga merupakan alat untuk mempromosikan nilai-nilai budaya dan juga sebagai identitas negara dimana telah hilang akibat dari intervensi eksternal dari negara-negara lain (Cheang (2009). Hal yang sama pun diungkapkan oleh Herrero et al (dalam Richards (2007), pada saat ini budaya memiliki dua peran yaitu mendukung memori kolektif dan identifikasi sosial serta sebagai 
sumber pemasukan dan kegiatan ekonomi.

Masyarakat Banjar Kaja selaku pemilik dari tradisi omed-omedan pun sadar akan pentingnya tradisi ini sebagai jati diri dari Banjar Kaja Desa Sesetan yang juga dapat memiliki dampak ekonomi didalamnya. Maka dari itu sejak tahun 2009 masyarakat Banjar Kaja mengemas tradisi ini kedalam sebuah festival, dimana didalamnya terdapat berbagai daya tarik pendukung serta wisata kuliner dan toko souvenir agar masyarakat sekitar mendapatkan keuntungan ekonomi dari tradisi ini. Masyarakat Banjar Kaja memiliki tujuan mengembangkan omed-omedan menjadi Sesetan Heritage Omed-omedan Festival (SHOOF), adalah untuk memperkenalkan tradisi ini ke masyarakat lebih luas dan agar bisa diketahui oleh para wisatawan baik domestik maupun mancanegara.

Peran masyarakat Banjar Kaja dalam menciptakan Sesetan Heritage Omed-omedan Festival adalah dengan membentuk panitia khusus yang akan mengatur segala kegiatan didalam festival ini. Pembentukan panitia dan rapat dilakukan beberapa bulan sebelum festival ini diadakan. Dalam rapat panitia tersebut masyarakat Banjar Kaja juga membahas pelaksanaan SHOOF pada tahun-tahun sebelumnya untuk membahas keberhasilan maupun permasalahan yang ditemui pada tahun sebelumnya. Hal ini dilakukan agar dapat memperbaiki kekurangan yang terjadi pada penyelenggaraan sebelumnya. Kegiatan promosi pun dibicarakan secara bersama-sama, promosi yang dilakukan oleh masyarakat Banjar Kaja selama ini adalah melalui media spanduk, radio lokal bali, media internet dan koran Bali.

Kegiatan pengumpulan dana juga dilakukan oleh masyarakat Banjar Kaja dengan cara pencarian sponsor kepada perusahaan yang terletak disekitar daerah Banjar Kaja Desa Sesetan, maupun dengan penjualan baju bertema Sesetan Heritage Omed-omedan Festival. Pada tahun 2014, masyarakat Banjar Kaja melakukan pengembangan SHOOF dengan membuat logo resmi, pada tanggal 1 April 2014 logo resmi SHOOF ditandatangani oleh Walikota Denpasar Rai D. Mantra yang kemudian akan dipakai pada tahuntahun berikutnya oleh masyarakat Banjar Kaja.

\section{Simpulan dan Saran}

Secara umum dapat disimpulkan bahwa Sesetan Heritage Omed-omedan Festival dapat menjadi daya tarik wisata, baik untuk turis domestik maupun mancanegara. Hal ini dapat dilihat dari keunikan tradisi yang bentuk fisiknya tidak ditemukan di daerah mana pun baik di Bali, Indonesia bahkan dunia. Kemauan masyarakat yang kuat dan didukung oleh kemampuan penyelenggaraan yang meningkat dari tahun ke tahun. Akses yang mudah dijangkau, hal ini dilihat dari dekatnya lokasi bandara internasional ngurah rai dan juga berbagai jenis transportasi umum yang ada untuk menuju tempat pelaksanaan omed-omedan. Peran pemerintah daerah sebagai pen- 
dukung pengembangan dan promosi dari tradisi omed-omedan. Sarana dan prasarana yang dimiliki oleh kota Denpasar, serta letak kota Denpasar yang berdekatan dengan kawasan wisata Sanur dan Kuta.

Waktu penyelenggaraan omed-omedan yang memang telah sesuai dengan agenda liburan para wisatawan. Waktu penyelenggaraan omedomedan ini jatuh serangkaian hari raya Nyepi yang merupakan satu set daya tarik wisata di mana wisatawan bisa menikmati tiga tradisi budaya yang unik: yaitu parade ogoh-ogoh, hari Nyepi dan kemudian pertunjukan tradisi omed-omedan. Pengunjung domestik merasa bangga hadir pada acara ini, walaupun bagi pengunjung dari mancanegara mengatakan kurang setuju akan hal tersebut. Ini terjadi karena kurangnya informasi dan pemahaman mengenai tradisi ini kepada mereka.

Omed-omedan merupakan budaya lokal yang dimiliki oleh Banjar Kaja Desa Sesetan yang telah diwariskan dan dilaksanakan secara turun temurun. Seiring dengan perkembangan waktu sebuah budaya tentunya akan terkena dampak dari modernisasi, begitu juga yang terjadi pada omed-omedan. Modernisasi yang terjadi pada tradisi omed-omedan adalah perubahan manajemen dalam pengelolaan yang semakin profesional dan terencana. Wisatawan yang hadir pada tradisi ini juga memiliki beberapa ketertarikan antara lain karena untuk memenuhi rasa keingin tahuan akan sebuah tradisi yang spesifik di kota Denpasar, dimana didalamnya terdapat berbagai nilai yang dapat diaplikasikan kedalam kehidupan sehari-hari serta dapat menumbuhkan semangat bagi diri sendiri. Selain hal tersebut wisatawan juga merasakan bangga jika hadir dalam tradisi yang hanya diadakan sekali dalam satu tahun ini. Selain datang untuk melihat tradisi omed-omedan, para wisatawan juga hadir pada SHOOF ini untuk menikmati atraksi pendukungnya seperti wisata kuliner.

Daya tarik dari omed-omedan sendiri dapat dikatakan mampu menjadi ikon bagi pariwisata internasional di kota Denpasar dengan melihat spesifik dan keunikan yang dimiliki oleh tradisi ini hanya diselenggarakan di kota Denpasar tepatnya Banjar Kaja itu sendiri. Namun, untuk menjadikan omed-omedan sebagai dayatarik pariwisata internasional di kota Denpasar maka ada beberapa hal yang harus diperhatikan yaitu adanya peraturan yang mengatur berbagai pihak yang ikut menyelenggarakan tradisi ini dan juga aturan etika untuk para pengunjung agar tidak menggangu jalannya tradisi ini.

Media promosi yang selama ini kurang beraneka ragam, diperlukannya kerja sama untuk mempromosikan tradisi omed-omedan ini kepada negaranegara potensial. Hal ini bisa dilakukan dengan bekerja sama dengan pusatpusat informasi pariwisata pada negara lain ataupun bekerja sama dengan berbagai travel agent yang ada di Indonesia untuk membuat sebuah paket wisata pada hari raya Nyepi, hal ini akan berpengaruh terhadap tingkat jumlah 
wisatawan yang hadir menyaksikan omed-omedan. Diperlukan tempat penyelenggaraan yang memadai untuk mampu menampung pengunjung secara nyaman, tempat penyelenggaraan omed-omedan di Banjar Kaja ini terletak di jalan raya tepat di depan Balai Banjar Kaja yang berdasarkan observasi kurang memadai namun hal tersebut tidak dapat dipindahkan karena alasan bentuk penghormatan atas kesakralan dari tradisi ini.

Saran yang dapat disampaikan adalah adalah sebagai berikut. Pertama, meningkatkan profesionalisme pengelolaan tradisi omed-omedan. Penyelenggaraan tradisi ini dari tahun ke tahun telah mengalami peningkatan kualitas, namun dirasakan perlu adalah mengemas penyelenggaraan tradisi ini sebagai sebuah event yang berkarakter kuat mewakili budaya Bali secara umum. Pelibatan seniman dan budayawan untuk mementaskan wujud seni dan budaya Bali sebelum puncak acara karena ini akan memperkuat daya tarik omed-omedan. Pelibatan banyak unsur seni dan budaya ini tentunya sangat menuntut profesionalisme dari Banjar Kaja karena itu pelatihan sebagai event organizer bertaraf internasional dirasakan sangat perlu.

Kedua, memperluas jaringan informasi dan kerja sama dengan pihakpihak yang dinilai dapat membantu dalam menghadirkan wisatawan.Walaupun event telah masuk dalam kalender wisata tahunan kota Denpasar, ternyata masih banyak biro perjalanan wisata yang tidak memprioritaskan acara ini sebagai bagian promosi perusahaannya. Pendekatan kepada biro perjalanan wisata perlu dilaksanakan untuk mempromosikan festival ini kepada wisawatan.

Ketiga, meningkatkan dan menjaga fasilitas dan infrastruktur pariwisata. Pada kondisi saat ini terbatasnya area pertunjukkan dari puncak acara omed-omedan dirasakan perlu untuk mendapat perhatian. Namun, dengan mengingat lokasi pertunjukan tidak dapat untuk dipindahkan dengan alasan penghormatan atas kesakralan tradisi ini maka hal ini dapat dilakukan dengan perluasan atau pelebaran jalan pada area lokasi. Kemudian fasilitas public service perlu ditingkatkan untuk memberikan rasa nyaman pada wisatawan, seperti toilet umum dan tempat parkir.

Keempat, menyiapkan informasi tentang omed-omedan. Untuk membantu para pengunjung baik wisatawan domestik maupun mancanegara untuk lebih memahami tradisi omed-omedan, maka perlu disertakan informasi yang detil, warga Banjar Kaja dapat mempersiapkan brosur berisi tentang bagaimana sejarah dari omed-omedan dan bagaimana tradisi ini dilakukan. Diharapkan agar tidak terjadi kesalahpahaman mengenai tradisi omed-omedan bukanlah sebuah tradisi melakukan ciuman di depan umum, namun hal tersebut bisa terjadi karena adanya gesekan antara muda-mudi disaat tradisi ini berlangsung.

Kelima, menetapkan tanggal pasti dari "Sesetan Heritage Omed-omedan Festival”. Karena pelaksanaan dari tradisi omed-omedan berdasarkan 
kalender Bali maka sangat penting untuk memberikan informasi tanggal pasti akan diselenggarakanya SHOOF kepada berbagai pihak terkait agar bisa melakukan promosi yang efektif.

\section{Ucapan Terima Kasih}

Penulis menyampaikan ucapan terima kasih kepada Prof. Dr. dr. A. A. Raka Sudewi, Sp.S (K) selaku Direktur Program Pascasarjana Universitas Udayana; Madame Sylvine Chevalier Pickel sebagai penanggung jawab akademik program Double Degree Indonesia Prancis mahasiswa Universitas Udayana Bali di Université d'Angers, France. Prof. Dr. I Nyoman Sirtha, SH.,MS., sebagai pendahulu Ketua Program Studi Kajian Pariwisata Program Pascasarjana Universitas Udayana, dan Prof. Dr. I Nyoman Darma Putra sebagai Ketua Program Studi Kajian Pariwisata Program Pascasarjana Universitas Udayana saat ini. Ucapan terima kasih juga penulis sampaikan kepada Bapak Nyoman Sunarta, M.Si sebagai Sekretaris Program Studi Kajian Pariwisata Program Pascasarjana Universitas Udayana terdahulu dan Dr. Ir. Syamsul Alam Paturusi, MSP sebagai Sekretaris Program Studi Kajian Pariwisata Program Pascasarjana Universitas Udayana saat ini. Ucapan terima kasih juga didedikasikan kepada Pemerintah Indonesia dan Prancis yang telah merancang Program Double Degree dan segala bentuk dukungan selama proses pendidikan. Juga terima kasih kepada keluarga, sahabat, dan seluruh pihak yang telah membantu untuk menyelesaikan tesis ini tepat pada waktunya.

\section{Daftar Pustaka}

Anam, Hairul. 2011."Modernisasi dan Perubahan Gaya Hidup Remaja Perempuan (Studi Remaja Perempuan Desa Duko, Kecamatan Arjasa, Kabupaten Sumenep)”. Skripsi.Progam Studi Sosiologi, Fakultas Ilmu Sosial dan Ilmu Budaya, Universitas Trunojoyo, Madura.

Chheang, Vannarith. 2009. Tourismos: An International Multidisciplinary. Journal of Tourism Volume 4, Number 1, Spring 2009, pp. 63-82.

Kartawinata, Ade M. 2011. "Pengantar Editor Merentas Kearifan Lokal di Tengah Modernisasi dan Tantangan Pelestarian. Buku Kearifan Lokal di Tengah Modernisasi”, Pusat Penelitian dan Pengembangan Kebudayaan Badan Pengembangan Sumber Daya Kebudayaan dan Pariwisata Kementerian Kebudayaan dan Pariwisata Republik Indonesia.

Muthe, Hadriana Marhaeni. 2008. Keterkaitan Perspektif Modernisasi dan Berbagai Studi Pembangunan Sosial. Jurnal Harmoni Sosial, Januari 2008, Volume II, No. 2.

Peraturan Daerah Provinsi Bali Nomor2 Tahun 2012 Tentang Kepariwisataan Budaya Bali

Purwana, Bambang H. Suta. 2011. Keserakahan Global yang Menang, Kearifan Lokal 
yang Malang: Proses Marginalisasi Masyarakat Dayak di Kalimantan Barat Buku Kearifan Lokal di Tengah Modernisasi. Pusat Penelitian dan Pengembangan Kebudayaan Badan Pengembangan Sumber Daya Kebudayaan dan Pariwisata Kementerian Kebudayaan dan Pariwisata Republik Indonesia.

Richards, Greg. 2007. Cultural Tourism Global and Local Perspectives. NY: The Haworth Hospitality Press.

Soebagyo. 2012. Strategi Pengembangan Pariwisata di Indonesia. Universitas Pancasila, Jakarta

\section{Profil Penulis}

I Wayan Didik Roy Mahardika, S.ST.Par adalah alumnus Magister Kajian Pariwisata, Double Degree Indonesia Prancis, dengan menempuh 1 tahun pendidikan Master di Universitas Udayana Denpasar kemudian melanjutkan 1 tahun berikutnya di Prancis tepatnya Université d'Angers, France jurusan Mention Management et Développement du Tourisme, de I'Hôtellerie, de la Restauration et des Loisirs. Ia menyelesaikan program studi Diploma IV, Administrasi Perhotelan di Sekolah Tinggi Pariwisata Nusa Dua Bali. Pengalaman yang dimiliki adalah pernah training selama 18 bulan di High Hampton inn and Country Club (NC - United Stated), kursus tentang hotel and restaurant management di South Western Community College (NC - United Stated), pernah bekerja di Holiday inn Resort Baruna Bali, Nyaman Villas Bali sebagai Assistant Front Office Manager. 